\title{
The content of dietary fiber, amino acids, dihydroxyphenols and some macro- and micronutrients in grain of conventionally and organically grown common wheat, spelt wheat and proso millet
}

\author{
Cezary A. Kwiatkowski ${ }^{1}$, Małgorzata Haliniarz ${ }^{1}$, Marta Tomczyńska-Mleko², \\ Stanisław Mleko ${ }^{3}$, Małgorzata Kawecka-Radomska ${ }^{4}$ \\ ${ }^{1}$ University of Life Sciences, Department of Herbology and Plant Cultivation Techniques, Akademicka 13, 20-950 Lublin, Poland \\ ${ }^{2}$ University of Life Sciences, Institute of Plant Genetics, Breeding and Biotechnology, \\ Akademicka 15, 20-950 Lublin, Poland \\ ${ }^{3}$ University of Life Sciences, Department of Biotechnology, Human Nutrition and Food Commodity Science, Skromna 8, 20-704 \\ Lublin, Poland \\ ${ }^{4}$ University of Life Sciences, Institute of Soil Science and Environmental Development, \\ Leszczyńskiego 7, 20-069 Lublin, Poland \\ e-mail: malgorzata.haliniarz@up.lublin.pl
}

\begin{abstract}
The effects of conventional and organic farming system on some quality parameters of grains were studied in winter and spring common wheat, spelt wheat and proso millet. Under organic farming conditions, spelt wheat was characterized by the most favorable grain chemical composition (essential amino acids index [EAAI] 85.3, o-dihydroxyphenol $2.00 \mathrm{~g} \mathrm{~kg}^{-1}$, nitrogen [N] $23.5 \mathrm{~g} \mathrm{~kg}^{-1}$, magnesium [Mg] 705, zinc [Zn] $32.9 \mathrm{mg} \mathrm{kg}^{-1}$ ), followed by millet (total dietary fiber [TDF] $185.3 \mathrm{~g} \mathrm{~kg}^{-1}, \mathrm{Mg} 904$, copper [Cu] 6.27, iron [Fe] $57.0 \mathrm{mg} \mathrm{kg}^{-1}$ ). The above-mentioned cereals also showed a satisfactory yield level under the organic system (spelt wheat 2.69, proso millet $1.42 \mathrm{t} \mathrm{ha}^{-1}$ ). Both in winter and spring common wheat organic farming led a significant reduction in productivity, but the content of chemical components in grain (dihydroxyphenols-spring wheat $1.68 \mathrm{~g} \mathrm{~kg}^{-1}$, winter wheat $1.74 \mathrm{~g} \mathrm{~kg}^{-1}$; selenium [Se]-spring wheat $53.4 \mathrm{mg} \mathrm{kg}^{-1}$, winter wheat $40.5 \mathrm{mg} \mathrm{kg}^{-1}$; some amino acids-spring wheat valine [Val] 5.11, methionine [Met] 2.09, tryptophan [Trp] $0.40 \mathrm{~g} \mathrm{~kg}^{-1}$, winter wheat glutamate [Glu] 41.9, proline [Pro] 15.3, glysine [Gly] 5.24, arginine [Arg] 5.04, [Trp] $0.97 \mathrm{~g} \mathrm{~kg}^{-1}$ ) was more favorable compared to the conventional system. The present study showed that the organic farming system does not result in reduced productivity neither in spelt wheat or proso millet, but contributes to an improvement in their grain quality parameters. On the other hand, common wheat performed better under the conventional system.
\end{abstract}

Key words: cereals, grain chemical composition, conventional system, organic system

\section{Introduction}

Cereal crops provide raw material for the production of many food products and the grains of cereals are the main source of carbohydrates, proteins, dietary fiber, vitamins, minerals, phenolics, inulin, sterols, etc. (Duthie et al. 2000, Fan et al. 2008, Ciołek et al. 2012, Shahidi and Chandrasekara 2013). Protein in spelt grain shows very high digestibility, at a level of $80-85 \%$ and compared to common wheat spelt grain it has more gluten (by $8 \%$ ) and oil (by 30\%) (Ruibal-Mendieta et al. 2004, Tyburski and Żuk-Gołaszewska 2005). Proso millet grain contains: $1-3 \%$ of oil, $70-83 \%$ of starch, $10.8-12.5 \%$ of protein, $11.0-12.5 \%$ of dietary fiber, and 2.8-3.2\% of ash (Baltensperger et. al. 1997, 2004). Spelt wheat or proso millet are known to have healthpromoting properties (Piironen et al. 2002). Spelt wheat contains phytosterols which depresses the blood cholesterol concentration and it also has a beneficial effect on the digestive system and stabilizes the nervous system functions (Piironen et al. 2002). Proso millet is recommended in gluten-free diet and for persons suffering from coeliac disease. In traditional Chinese medicine, tumors - even at an advanced stageare treated using a very strict and consistent diet consisting of $50 \%$ cereal grains (mainly millet grains), $30 \%$ vegetables and $20 \%$ (Acko 2012).

Agricultural producers and consumers are more and more aware of the need both to produce and consume healthy foods free of chemicals and to take care of the environment in which we live. Attention is generally paid to the possibility of potential food contamination with residues of crop protection agents or nitrates. Thus, the demand for organic products is increasing. There is a view among consumers, which is confirmed by the results of many experiments, that food produced using organic methods has a better taste as well as more nutrients, vitamins and minerals (Hajšlová et al. 2005, Mäder et al. 2007, Brocic et al. 2008, Wang et al. 2008). Moreover, organic farming exerts lower pressure on the natural environment and climate changes (Bavec et al. 2011). 
The organic farming system generally has a positive effect on cereal grain quality, while grain yield is lower than under conventional farming. This results from the fact that the use of mineral NPK fertilization is abandoned and also from the lack of use of crop protection chemicals (in particular herbicides and fungicides). In particular, the use of mineral $\mathrm{N}$ fertilization is the main yield-enhancing factor under conventional cereal cropping (Cassman 1999, Demirbas 2005, Seufert et al. 2012, Kraska et al. 2013). Some cereals - such as spelt wheat and proso millet- are genetically suited for lower habitat and fertilization requirements as well as extensive crop protection and they produce equally high yields under both organic and conventional farming (Tybulski and Żuk-Gołaszewska 2005).

In the present study we have made a hypothesis that growing cereals using the organic farming system, in spite of the possibility of reducing their productivity (grain yield), would contribute to an improvement in some quality parameters affecting the health-promoting value of grain compared to conventional farming. An assumption was made that in particular spelt wheat and proso millet would tolerate well the organic farming system. This applies not only to grain productivity, but in particular to the content of valuable nutrients in grain.

The aim of the present study was to determine the content of some nutrients in grain of four cereals (winter and spring wheat, spelt wheat, and proso millet) which determine their health-promoting properties and to compare the productivity of these cereals under conventional and organic farming.

\section{Materials and Methods Experimental design}

A field experiment in growing common wheat (winter wheat cv. 'Bockris' and spring wheat cv. 'Nawra'), spelt wheat cv. 'Schwabencorn', and proso millet cv. 'Jagna' was carried out in the village of Fajsławice (located in the central part of the Lublin region, Poland) over the period 2011-2013. The experiment was set up as a split-plot design with 3 replicates, in $27 \mathrm{~m}^{2}$ plots. The above-mentioned cereal species were grown on grey-brown podzolic soil ( $\mathrm{pH}$ in $1 \mathrm{M} \mathrm{KCl}=6.3$ ) classified as good wheat soil complex. Before the experiment was established, the soil was characterized by a medium content of available macronutrients (phosphorus $[\mathrm{P}]=79.8$, potassium $[\mathrm{K}]=85.4$, $\mathrm{Mg}=30.7 \mathrm{mg} \mathrm{kg}^{-1}$ ). The average humus content was $1.43 \%$.

Two cereal cropping systems were used in the experiment: 1 . Conventional farming - the recommended rates of mineral fertilization (NPK), seed dressing, fungicide and herbicide use, mechanical weed control (harrowing before emergence and at the 3-4 leaf stage); 2. Organic farming - fertilization using an organic fertilizer (Humac Agro), mechanical weed control (harrowing before emergence and at the 3-4 leaf stage).

In each year of the study, potato cv. 'Bryza' was the previous crop for all the cereal species. Each year, the same mineral fertilization was used for the individual cereals. In the organic farming treatment, mineral fertilization was as follows ( $\mathrm{kg} \mathrm{ha}^{-1}$ ): spring and winter common wheat: $\mathrm{N} 100 \mathrm{~kg}$ (40 kg before sowing, $40 \mathrm{~kg}$ of the dose in spring right at the beginning of plant growth (BBCH 21-24), $20 \mathrm{~kg}$ at the turn of stem elongation and heading (BBCH 3236), P $26 \mathrm{~kg}$ (before sowing), K $66 \mathrm{~kg}$ (before sowing); spelt wheat: $\mathrm{N} 60 \mathrm{~kg}$ (20 kg before sowing, $40 \mathrm{~kg}$ in spring at stem elongation (BBCH 32-34), P 26 kg (before sowing), $\mathrm{K} 58 \mathrm{~kg}$ (before sowing); proso millet: N $40 \mathrm{~kg}, \mathrm{P} 30 \mathrm{~kg}$, $\mathrm{K} 50 \mathrm{~kg}$ (all fertilizers before sowing).

In the case of organic farming, the fertilizer Humac Agro (the composition of dry matter: humic acids $62 \%$ (free humic acids 50\%), natrium (Na) $12801 \mathrm{mg} \mathrm{kg}^{-1}, \mathrm{~K} 1186 \mathrm{mg} \mathrm{kg}^{-1}$, calcium (Ca) $16805 \mathrm{mg} \mathrm{kg}^{-1}, \mathrm{Zn} 6 \mathrm{mg} \mathrm{kg}^{-1}$, bromine (Br) $77 \mathrm{mg} \mathrm{kg}^{-1}$, Fe $14502 \mathrm{mg} \mathrm{kg}^{-1}$, Cu $19 \mathrm{mg} \mathrm{kg}^{-1}$, Se $6 \mathrm{mg} \mathrm{kg}^{-1}$, humidity 20\%), was applied at the following amount $\left(\mathrm{kg} \mathrm{ha}^{-1}\right)$ : spring and winter common wheat: $450 \mathrm{~kg}$ (before sowing); spelt wheat: $350 \mathrm{~kg}$ (before sowing); proso millet: $250 \mathrm{~kg}$ (before sowing). Seeds of cereals (spring wheat, winter wheat, spelt wheat, proso millet) grown under the conventional system were dressed with Raxil 060 FS (tebuconazole) at a rate of $50 \mathrm{ml} \mathrm{per} 100 \mathrm{~kg}^{-1}$ of seed. Seeds of the individual cereal species were sown at the following amounts and on the following dates: spring wheat $\left(200 \mathrm{~kg} \mathrm{ha}^{-1}\right)$ in the second 10-day period of April, winter wheat ( $\left.220 \mathrm{~kg} \mathrm{ha}^{-1}\right)$ in the third 10-day period of September, spelt wheat ( $300 \mathrm{~kg} \mathrm{ha}^{-1}$ of spikelets) in the third 10 -day period of September, and proso millet (4 kg $\left.\mathrm{ha}^{-1}\right)$ in the second 10-day period of May.

Under conventional weed control, the following crop protection agents were used: spring and winter common wheat: herbicide Sekator 6,25 WG (amidosulfuron + iodosulfuron-methyl-sodium + mefenpyr-diethyl) $0.25 \mathrm{~kg} \mathrm{ha}^{-1}$ at tillering $\mathrm{BBCH}$ 27-28; fungicide Alert 375 SC (flusilazole + carbendazim) $1.01 \mathrm{ha}^{-1}$ (at stem elongation BBCH 3132); spelt wheat: herbicide Sekator 6,25 WG (amidosulfuron + iodosulfuron-methyl-sodium + mefenpyr-diethyl) $0.25 \mathrm{~kg} \mathrm{ha}^{-1}$ at tillering BBCH 27-28; fungicide Alert $375 \mathrm{SC}$ (flusilazole + carbendazim) 1.0 I ha ${ }^{-1}$ (at stem elongation $\mathrm{BBCH} 31-32)$; proso millet: herbicide Gold 450 EC (2,4-D, fluroxypyr) 0.8 I ha ${ }^{-1}$ at tillering BBCH 27-28); no fungicide was used (millet is tolerant to fungal diseases). 


\section{Meteorological conditions}

The annual rainfall totals in the period 2010-2013 were similar and at the same time distinctly lower than the long-term means. The mean air temperatures were also almost identical in individual growing seasons but higher than the long-term mean temperatures. Throughout the study period, however, there were certain differences for some months of the cereals growing period (Table 1).

Table 1. Rainfall and air temperature in 2010-2013 as compared to the long-term mean figures (1974-2003) in Fajsławice

\begin{tabular}{|c|c|c|c|c|c|c|c|c|c|c|c|c|c|}
\hline \multirow[b]{2}{*}{ Year } & \multicolumn{11}{|c|}{ Month } & \multirow[b]{2}{*}{ XII } & \multirow[b]{2}{*}{$\begin{array}{l}\text { Total } \\
\text { I-XII }\end{array}$} \\
\hline & 1 & II & III & IV & V & VI & VII & VIII & IX & $x$ & $X I$ & & \\
\hline \multicolumn{14}{|c|}{ Rainfall mm } \\
\hline 2010 & 70.2 & 48.2 & 29.4 & 40.7 & 50.3 & 47.4 & 70.3 & 50.3 & 42.2 & 46.3 & 40.4 & 33.9 & 569.7 \\
\hline 2011 & 64.2 & 43.4 & 30,4 & 18.2 & 45.8 & 79.3 & 52.2 & 41.7 & 44.9 & 50.1 & 35.5 & 38.2 & 543.9 \\
\hline 2012 & 53.9 & 39.9 & 18.6 & 16.0 & 66.3 & 36.7 & 99.7 & 23.9 & 30.5 & 47.4 & 43.4 & 44.6 & 520.9 \\
\hline 2013 & 68.3 & 45.1 & 38.4 & 52.4 & 26.6 & 66.1 & 66.8 & 37.8 & 41.1 & 40.8 & 38.2 & 40.1 & 561.7 \\
\hline \multirow[t]{2}{*}{$\begin{array}{c}\text { Mean } \\
1974-2003\end{array}$} & 71.8 & 46.7 & 29.7 & 44.2 & 58.7 & 80.4 & 79.0 & 68.2 & 57.2 & 48.3 & 41.5 & 35.9 & 661.6 \\
\hline & \multicolumn{12}{|c|}{ Temperature ${ }^{\circ} \mathrm{C}$} & $\begin{array}{c}\text { Mean } \\
1 \text {-XII }\end{array}$ \\
\hline 2010 & -2.7 & -0.8 & 1.6 & 6.4 & 12.2 & 16.4 & 18.0 & 17.6 & 12.2 & 7.0 & 5.3 & -0.4 & 7.7 \\
\hline 2011 & -3.2 & -0.9 & 2.1 & 7.3 & 16.7 & 17.0 & 19.3 & 18.2 & 13.4 & 7.8 & 6.6 & -1.1 & 8.6 \\
\hline 2012 & -3.1 & -1.2 & 1.9 & 6.5 & 15.9 & 17.4 & 19.4 & 18.3 & 13.1 & 7.2 & 6.1 & -0.2 & 8.4 \\
\hline 2013 & -2.0 & 0.3 & 2.6 & 7.7 & 11.6 & 17.5 & 19.8 & 18.4 & 13.2 & 8.2 & 6.4 & 0.6 & 8.6 \\
\hline $\begin{array}{c}\text { Mean } \\
1974-2003\end{array}$ & -2.9 & 0.2 & 2.2 & 7.7 & 13.6 & 16.5 & 17.9 & 17.6 & 11.3 & 7.1 & 4.2 & -0.5 & 7.9 \\
\hline
\end{tabular}

\section{Chemical analyses of soil}

Before the establishment of the experiment (2010/2011) and at the time of harvest of the cereals studied (2011, 2012, 2013), the major soil chemical properties were determined for the $0-20 \mathrm{~cm}$ layer: soil pH was determined electrometrically in water and in $1 \mathrm{M} \mathrm{KCl}$, the content of available forms of $\mathrm{P}$ and $\mathrm{K}$ by the Egner-Riehm method, whereas the $\mathrm{Mg}$ content using $0.01 \mathrm{M} \mathrm{CaCl}_{2}$ (Houba et al. 1994). The soil humus content was determined by alkaline extraction using the following reagents: $\mathrm{NaOH}$ and $\mathrm{Na}_{2} \mathrm{O}_{3}$ at concentrations of $0.1 \mathrm{M}$ to $0.5 \mathrm{M}$.

\section{Chemical analyses of grain}

$\mathrm{N}$ content was carried out the Kjeldahl method (ISO 5983-1, Animal feeding stuffs, Determination of nitrogen content and calculation of crude protein content, Part 1: Kjeldahl method).

Grain amino acid content was determined by HPLC (AAA 400, Ingos, Prague, Czech Republic). The amino acids were separated by ion exchange chromatography. A $0.37 \times 45 \mathrm{~cm}$ column was filled with ion-exchange resin (Ostion LG ANB, Tessek, Praha, Czech Republic). Amino acid identification was done using a photometric detector at a wavelength of $570 \mathrm{~nm}$ for all amino acids, and only for Pro at $440 \mathrm{~nm}$.

Total dihydroxyphenol content was measured spectrophotometrically at a wavelength of $\lambda=725 \mathrm{~nm}$ (Shimadzu 1800 spectrophotometer, Shimadzu Corp. Kyoto, Japan) and expressed as caffeic acid equivalents. To make the measurement on the spectrophotometer, $50 \mu \mathrm{l}-500 \mu \mathrm{l}$ of the extract (depending on the expected value of absorption of the tested sample) was transferred into a volumetric flask. $2.0 \mathrm{ml}$ methanol, $10 \mathrm{ml} \mathrm{H}_{2} \mathrm{O}, 2 \mathrm{ml}$ Folin reagent, and $1.0 \mathrm{ml}$ of a $10 \%$ solution of $\mathrm{Na}_{2} \mathrm{CO}_{3}$ were added. The samples were put aside for $0.5 \mathrm{~h}$ and subsequently they were made up with deionized water up to the mark and measured on the spectrophotometer at a wavelength of $\lambda=725 \mathrm{~mm}$ in relation to the reference sample.

The phenolic concentration in the extract was expressed as caffeic acid equivalents using the following formula:

$$
\mathrm{Z}\left(\mathrm{mg} \mathrm{ml}^{-1}\right)=\frac{c}{V}
$$

$\mathrm{c}$ - phenolic content ( $\mathrm{mg}$ ) in the sample read from the calibration curve

$\mathrm{V}$-extract volume taken for analysis $(\mathrm{ml})$ 
The phenolic concentration in the material was expressed as caffeic acid equivalents using the following formula:

$$
\mathrm{Z}\left(\mathrm{g} 100 \mathrm{~g}^{-1}\right)=\frac{5 c}{V m}
$$

$\mathrm{c}$ - phenolic content $(\mathrm{mg})$ in the sample read from the calibration curve

$\mathrm{V}$-extract volume taken for analysis $(\mathrm{ml})$

$\mathrm{m}$-weighed portion of material $(\mathrm{g})$

Total dietary fiber content was determined by the enzymatic gravimetric method using a Fibertec 2010 system (FOSS, Hillerød, Denmark). The sample was subjected to digestion with the following enzymes: thermostable alpha-amylase, pepsin, and pancreatin, the weight of the undigested residue was determined, and the soluble dietary fiber supernatant was precipitated from the solution and its weight was determined.

Mineral analysis of the isolate was performed by atomic absorption spectrometry using a Varian SpectrAA 280 FS spectrophotometer (Varian, Inc., Palo Alto, USA). The conditions of determination of the individual elements were as follows: potassium emission (without lamp), wavelength $766.5 \mathrm{~nm}$, slit $0.2 \mathrm{~nm}$, flame acetylene/air (stoichiometric ratio); calcium Varian lamp, current $10 \mathrm{~mA}$, wavelength $422.7 \mathrm{~nm}$, slit $0.5 \mathrm{~nm}$, flame acetylene/air (stoichiometric ratio); magnesium Varian lamp, current $4 \mathrm{~mA}$, wavelength $202.6 \mathrm{~nm}$, slit $1.0 \mathrm{~nm}$, flame acetylene/ air (stoichiometric ratio), iron Varian lamp, current $5 \mathrm{~mA}$, wavelength $248.3 \mathrm{~nm}$, slit $0.2 \mathrm{~nm}$, flame acetylene/air (stoichiometric ratio); manganese Varian lamp, current $5 \mathrm{~mA}$, wavelength $279.5 \mathrm{~nm}$, slit $0.2 \mathrm{~nm}$, flame acetylene/ air (stoichiometric ratio); zinc Varian lamp, current $5 \mathrm{~mA}$, wavelength $213.9 \mathrm{~nm}$, slit $1.0 \mathrm{~nm}$, flame acetylene/air (stoichiometric ratio); copper Varian lamp, current $5 \mathrm{~mA}$, wavelength $324.8 \mathrm{~nm}$, slit $0.5 \mathrm{~nm}$, flame acetylene/air (stoichiometric ratio); selenium Varian lamp, wavelength $196.0 \mathrm{~nm}$ or $204 \mathrm{~nm}$.

\section{Statistical calculations and analysis}

The results were analyzed statistically by analysis of variance (ANOVA). LSD values were determined by Tukey's test at $p=0.05$.

The Essential Amino Acids Index (EAAI) was calculated as the geometric mean of all essential amino acids in relation to the content of these amino acids in the egg reference protein (FAO 1985).

The EAAI was calculated according to the following formula:

$$
E A A I=\sqrt[n]{\left(\frac{a_{1}}{a_{1 s}}\right) \times 100 \times \ldots \times\left(\frac{a_{n}}{a_{n s}}\right) \times 100}=10^{\operatorname{logEAAI}}
$$

$a_{n}$-amino acid content in the protein tested

$a_{n s}$ - amino acid content in the reference protein.

\section{Results}

\section{Soil conditions}

After a three-year cycle of field experiments, it should be concluded that regardless of the cereal species the conventional farming system (application of NPK mineral fertilization) had a positive effect on increasing the P and $\mathrm{K}$ content in the soil plough layer (Table 2). Organic farming, in which the fertilizer Humac Agro was used, in turn promoted higher $\mathrm{Mg}$ accumulation and higher soil humus content. No clear differences were however found in the determined soil quality characteristics ( $\mathrm{P}, \mathrm{K}, \mathrm{Mg}$, \% humus) between the individual cereal species, both under conventional and organic farming. 
C.A. Kwiatkowski et al. (2015) 24: 195-205

Table 2. Results of some chemical determinations for the plough layer $(0-30 \mathrm{~cm})$ in the experiment - mean for $2011-2013$

\begin{tabular}{|c|c|c|c|c|c|c|c|c|}
\hline \multirow{2}{*}{ Species } & \multicolumn{4}{|c|}{ Conventional } & \multicolumn{4}{|c|}{ Organic } \\
\hline & $\mathrm{P} \mathrm{mg} \mathrm{kg}^{-1}$ & $\mathrm{~K} \mathrm{mg} \mathrm{kg}^{-1}$ & $\mathrm{Mg}_{\mathrm{kg}} \mathrm{mg}^{-1}$ & $\%$ humus & $\mathrm{P} \mathrm{mg} \mathrm{kg}^{-1}$ & $\mathrm{~K} \mathrm{mg} \mathrm{kg}^{-1}$ & $\mathrm{Mg}_{\mathrm{kg}} \mathrm{mg}^{-1}$ & $\%$ humus \\
\hline Spring wheat & 79.9 & 87.2 & 29.4 & 1.40 & 78.8 & 86.4 & 30.7 & 1.45 \\
\hline Winter wheat & 80.2 & 88.0 & 28.8 & 1.41 & 79.1 & 87.2 & 29.8 & 1.47 \\
\hline Spelt wheat & 79.4 & 87.6 & 28.6 & 1.39 & 79.0 & 87.0 & 29.7 & 1.44 \\
\hline Proso millet & 80.5 & 88.1 & 29.0 & 1.38 & 78.6 & 86.5 & 30.5 & 1.42 \\
\hline
\end{tabular}

\section{Total dietary fiber content}

The TDF in spring and winter wheat grain as well as in millet grain did not differ significantly between conventional and organic farming systems (Table 3). In the case of spelt grain, however, the TDF had significantly higher values in the organic farming treatment (by more than $9.8 \%$ ). Both under conventional and organic farming, significantly the lowest TDF content was found in winter wheat and spelt wheat grain, whereas it was highest in proso millet.

Table 3. Total dietary fiber (TDF) content in cereal grain $\left(\mathrm{g} \mathrm{kg}^{-1}\right)$-mean for 2011-2013

\begin{tabular}{|c|c|c|}
\hline \multirow{2}{*}{ Species } & \multicolumn{2}{|c|}{ Farming system } \\
\hline & Conventional & Organic \\
\hline Spring wheat & $165.8(27.5)$ a $\mathrm{A}$ & $170.6(28.3)$ a $A$ \\
\hline Winter wheat & $134.4(22.3)$ a B & $141.0(23.4)$ a B \\
\hline Spelt wheat & $136.1(22.6)$ a B & $150.9(25.0) b \mathrm{~B}$ \\
\hline Proso millet & $181.7(30.2)$ a $C$ & $185.3(30.8)$ a C \\
\hline
\end{tabular}

\section{Amino acid content}

The two cereal cropping systems had a different effect on the grain amino acid content (Table 4). As far as spring wheat is concerned, in most cases organic farming resulted in a significant decrease in the grain amino acid content (Thr, Ser, Glu, Pro, Gly, Ala, Cys-A, Ile, Leu, Tyr, Phe, His, Arg) compared to conventional farming. Organic farming only had a positive effect on a significantly higher content of the following amino acids in spring wheat grain: Val (by about 10\%), Met (by about 50\%), and Trp (by about $12 \%$ ).

Winter wheat proved to be more tolerant to organic farming than the spring form of this cereal (Table 4). Organic farming caused a significant increase in the grain content of the following amino acids: Glu (by 8\%), Pro (by 8.5\%), Gly (by 9\%), Arg (by 9\%), and Trp (39\%). At the same time, the organic cropping system reduced the content of the following amino acids in winter wheat grain: Ala (by about 18\%) and Cys-A (by as much as 2.5 times).

Table 4. Amino acid content in cereal grain $\left(\mathrm{g} \mathrm{kg}^{-1}\right)$-mean for 2011-2013

\begin{tabular}{|c|c|c|c|c|c|c|c|c|}
\hline \multirow{2}{*}{ Parameter } & \multicolumn{2}{|c|}{ Spring wheat } & \multicolumn{2}{|c|}{ Winter wheat } & \multicolumn{2}{|c|}{ Spelt wheat } & \multicolumn{2}{|c|}{ Proso millet } \\
\hline & $\mathrm{CS}$ & OS & CS & OS & CS & OS & $\mathrm{CS}$ & OS \\
\hline Asn (asparagine) & $6.24 \mathrm{a}$ & $5.80 \mathrm{a}$ & $6.02 \mathrm{a}$ & $6.09 \mathrm{a}$ & $6.87 \mathrm{a}$ & $6.36 \mathrm{a}$ & $6.41 \mathrm{a}$ & $6.01 \mathrm{a}$ \\
\hline Thr (threonine) & $3.74 \mathrm{a}$ & $3.40 \mathrm{~b}$ & $3.54 \mathrm{a}$ & $3.58 \mathrm{a}$ & $4.08 \mathrm{a}$ & $3.83 \mathrm{a}$ & $3.30 \mathrm{a}$ & $3.06 \mathrm{a}$ \\
\hline Ser (serine) & 6.39 a & $5.60 \mathrm{~b}$ & $6.28 \mathrm{a}$ & $6.26 \mathrm{a}$ & $6.78 \mathrm{a}$ & $6.55 \mathrm{a}$ & $6.71 \mathrm{a}$ & $6.19 \mathrm{a}$ \\
\hline Glu (glutamine) & $39.3 \mathrm{a}$ & $34.4 \mathrm{~b}$ & $38.6 \mathrm{a}$ & $41.9 \mathrm{~b}$ & $45.5 \mathrm{a}$ & $45.3 \mathrm{a}$ & $24.1 \mathrm{a}$ & $22.0 \mathrm{~b}$ \\
\hline Pro (proline) & $13.9 \mathrm{a}$ & $12.7 \mathrm{~b}$ & $14.0 \mathrm{a}$ & $15,3 \mathrm{~b}$ & $16.5 \mathrm{a}$ & $16.7 \mathrm{a}$ & $8.73 \mathrm{a}$ & $7.68 \mathrm{~b}$ \\
\hline Gly (glysine) & $5.16 \mathrm{a}$ & $4.77 b$ & $4.76 \mathrm{a}$ & $5.24 b$ & $5.61 \mathrm{a}$ & $5.34 \mathrm{a}$ & $2.86 \mathrm{a}$ & $2.62 \mathrm{a}$ \\
\hline Ala (alanine) & $4.91 \mathrm{a}$ & $4.26 \mathrm{~b}$ & $5.19 \mathrm{a}$ & $4.24 b$ & $4.75 \mathrm{a}$ & $4.48 \mathrm{a}$ & $10.3 \mathrm{a}$ & $9.70 \mathrm{a}$ \\
\hline Cys-A (cysteine-A) & $3.16 \mathrm{a}$ & $1.78 \mathrm{~b}$ & $3.52 \mathrm{a}$ & $1.43 \mathrm{~b}$ & $2.50 \mathrm{a}$ & $2.45 \mathrm{a}$ & $2.25 \mathrm{a}$ & $0.57 \mathrm{~b}$ \\
\hline Val (valine) & $4.60 \mathrm{a}$ & $5.11 b$ & $4.83 \mathrm{a}$ & $4.99 \mathrm{a}$ & $5.52 \mathrm{a}$ & $5.56 \mathrm{a}$ & $4.49 \mathrm{a}$ & $4.81 \mathrm{a}$ \\
\hline Met (metionine) & $1.04 \mathrm{a}$ & $2.09 \mathrm{~b}$ & $2.12 \mathrm{a}$ & $2.22 \mathrm{a}$ & $1.64 \mathrm{a}$ & $4.07 \mathrm{~b}$ & $1.76 \mathrm{a}$ & $3.17 b$ \\
\hline Ile (isoleusine) & $4.00 \mathrm{a}$ & $3.52 b$ & $3.89 \mathrm{a}$ & 3.99 a & $4.36 \mathrm{a}$ & $4.47 \mathrm{a}$ & $3.79 \mathrm{a}$ & $3.56 \mathrm{a}$ \\
\hline Leu (leusine) & $8.70 \mathrm{a}$ & $7.60 \mathrm{~b}$ & $8,88 \mathrm{a}$ & $8.46 \mathrm{a}$ & $9.36 \mathrm{a}$ & $9.37 \mathrm{a}$ & $12.3 \mathrm{a}$ & $11.5 \mathrm{a}$ \\
\hline Tyr (tyrosine) & $2.72 \mathrm{a}$ & $2.22 \mathrm{~b}$ & $2.56 \mathrm{a}$ & $2.65 \mathrm{a}$ & $3.00 \mathrm{a}$ & $2.77 \mathrm{a}$ & $2.96 \mathrm{a}$ & $2.64 \mathrm{a}$ \\
\hline Phe (phenylalanine) & $5.67 \mathrm{a}$ & $4.99 \mathrm{~b}$ & $5.64 \mathrm{a}$ & $5.74 \mathrm{a}$ & $6.24 \mathrm{a}$ & $6.12 \mathrm{a}$ & $5.63 a$ & $5.14 \mathrm{a}$ \\
\hline His (histidine) & $2.90 \mathrm{a}$ & $2.63 b$ & $2.73 \mathrm{a}$ & $2,86 \mathrm{a}$ & $3.23 \mathrm{a}$ & $3.20 \mathrm{a}$ & $2.38 \mathrm{a}$ & $2.19 a$ \\
\hline Lys (lysine) & $3.29 \mathrm{a}$ & $3.17 \mathrm{a}$ & $3.00 \mathrm{a}$ & $3.28 \mathrm{a}$ & $3.67 a$ & $3.35 \mathrm{a}$ & $1.91 \mathrm{a}$ & $1.72 \mathrm{a}$ \\
\hline Arg (arginine) & $5.17 \mathrm{a}$ & $4.61 b$ & $4.58 \mathrm{a}$ & $5.04 \mathrm{~b}$ & $5.39 \mathrm{a}$ & $5.08 \mathrm{a}$ & $3.42 \mathrm{a}$ & $3.14 \mathrm{a}$ \\
\hline Trp (tryptophan) & $0.35 a$ & $0.40 \mathrm{~b}$ & $0.60 \mathrm{a}$ & $0.97 b$ & $0.51 \mathrm{a}$ & $0.86 \mathrm{~b}$ & $0.39 a$ & $0.58 \mathrm{~b}$ \\
\hline EAAI & $69.0 \mathrm{a}$ & $65.3 \mathrm{a}$ & $74.0 \mathrm{a}$ & $76.0 \mathrm{a}$ & 77.9 a & $85.3 \mathrm{~b}$ & $65.1 \mathrm{a}$ & $64.4 \mathrm{a}$ \\
\hline
\end{tabular}

Means marked in rows with different letters $(a-b)$ for the individual cereal species are significantly different $(p=0.05)$; CS = conventional system; OS = organic system; EAAI = essential amino acid index 


\section{AGRICULTURAL AND FOOD SCIENCE}

C.A. Kwiatkowski et al. (2015) 24: 195-205

The content of the individual amino acids in spelt grain proves that this cereal is tolerant to organic farming and the related lack of use of mineral fertilization (NPK) and crop protection chemicals. Except for Met and Trp, the content of the other amino acids in grain of this cereal harvested from organically and conventionally grown crops did not differ significantly. Organic farming of spelt wheat resulted in a 2.5 times higher content of Met and a 1.7 times higher content of Trp compared to conventional farming (Table 4).

Proso millet grain was also found to have a significantly higher content of Met (1.8 times) and Trp (1.5 times) under organic farming conditions relative to conventional cropping. As regards the content of the other amino acids in millet grain it was found a significantly higher content of Glu (by $9 \%$ ) and Pro (by $12 \%$ ) in grain from the conventional farming treatment (Table 4). Only in the case of spelt wheat, grain from organic farming was characterized by a significantly higher value of the EAAl compared to conventional farming (Table 4).

\section{O-dihydroxyphenol content}

On average during the study period, the content of ortho-dihydroxyphenols in grain of all the cereals analyzed was significantly higher in the organic farming treatment compared to conventional farming: spring wheat and winter wheat by about $7 \%$, spelt wheat by $16 \%$, and proso millet by $11 \%$. This shows that organic cropping favors higher accumulation of these valuable natural antioxidants in cereal grain. Regardless of the farming system, the highest o-dihydroxyphenol content was found in spelt grain, while the lowest one in millet grain (Table 5).

Table 5. O-dihydroxyphenol content (the total expressed as caffeic acid equivalents) in cereal grain ( $\left.\mathrm{g} \mathrm{kg}^{-1}\right)$; mean for 2011-2013

\begin{tabular}{lcc}
\hline Species & Conventional & Farming system \\
\cline { 1 - 1 } Spring wheat & $1.56(0.41)$ a A & Organic \\
Winter wheat & $1.62(0.42)$ a A & $1.68(0.44)$ b A \\
Spelt wheat & $1.68(0.44)$ a A & $1.74(0.45)$ b A \\
Proso millet & $0.48(0.12)$ a B & $2.00(0.52)$ b B \\
Means marked in rows with different letters $(\mathrm{a}-\mathrm{b})$ for the individual cereal species are significantly different $(p=0.05)$ \\
Means marked in columns with different letters (A-C) for the individual farming system are significantly different $(p=0.05)$
\end{tabular}

\section{Content of some macro- and micronutrients}

The conventional farming system resulted in a higher $\mathrm{N}$ content compared to the organic system only in the in the case of spring wheat (Table 6). The K content was significantly higher in grain of conventionally grown spring wheat, winter wheat, and spelt wheat. A significantly higher Mg content (on average by about $16 \%$ ) was found in grain of organically grown spelt wheat compared to conventional cropping. In the case of spring wheat, on the other hand, a reverse relationship was found (there was significantly more $\mathrm{Mg}$ in conventionally grown grain). The Ca content in grain from all the cereals analyzed was significantly higher under conventional farming conditions. In turn, organic farming resulted in a significantly higher Cu content in grain of all the cereals by respectively: $25 \%$ (spring wheat), 17\% (winter wheat), 8\% (spelt wheat), and 19\% (proso millet). The Mg, Fe and Zn content in spring and winter wheat grain was significantly higher under conventional farming conditions, whereas the content of $\mathrm{Mn}$, Fe and $\mathrm{Zn}$ in spelt and millet grain showed statistically proven higher values as a result of organic farming (Table 6).

Table 6. Content of some macro- and micronutrients in cereal grain; mean for 2011-2013

\begin{tabular}{|c|c|c|c|c|c|c|c|c|}
\hline \multirow{2}{*}{ Nutrient } & \multicolumn{2}{|c|}{ Spring wheat } & \multicolumn{2}{|c|}{ Winter wheat } & \multicolumn{2}{|c|}{ Spelt wheat } & \multicolumn{2}{|c|}{ Proso millet } \\
\hline & CS & OS & $\mathrm{CS}$ & OS & $\mathrm{CS}$ & OS & $\mathrm{CS}$ & OS \\
\hline $\mathrm{N}\left(\mathrm{g} \mathrm{kg}^{-1}\right)$ & $21.6 \mathrm{a}$ & $18.7 b$ & $20.6 a$ & $20.7 a$ & $23.4 \mathrm{a}$ & $23.5 \mathrm{a}$ & $17.9 \mathrm{a}$ & $17.8 \mathrm{a}$ \\
\hline $\mathrm{Mg}\left(\mathrm{mg} \mathrm{kg}^{-1}\right)$ & 793 a & 694 b & 665 a & 663 a & 590 a & $705 \mathrm{~b}$ & $922 \mathrm{a}$ & $904 \mathrm{a}$ \\
\hline $\mathrm{Ca}\left(\mathrm{mg} \mathrm{kg}^{-1}\right)$ & 355 a & $287 b$ & 290 a & $240 \mathrm{~b}$ & $256 a$ & 194 b & $212 \mathrm{a}$ & $176 \mathrm{~b}$ \\
\hline $\mathrm{Cu}\left(\mathrm{mg} \mathrm{kg}^{-1}\right)$ & $3.35 \mathrm{a}$ & $4.48 b$ & $2.67 \mathrm{a}$ & $3.21 b$ & $3.66 \mathrm{a}$ & $3.98 b$ & $5.08 \mathrm{a}$ & $6.27 b$ \\
\hline $\mathrm{Fe}\left(\mathrm{mg} \mathrm{kg}^{-1}\right)$ & $41.5 \mathrm{a}$ & $33.7 b$ & $34.0 \mathrm{a}$ & $29.0 \mathrm{~b}$ & $36.4 \mathrm{a}$ & $39.2 b$ & $47.7 \mathrm{a}$ & $57.0 \mathrm{~b}$ \\
\hline $\mathrm{Zn}\left(\mathrm{mg} \mathrm{kg}^{-1}\right)$ & $26.8 \mathrm{a}$ & $23.5 b$ & $34.0 \mathrm{a}$ & $29,0 \mathrm{~b}$ & $27.9 a$ & $32.9 \mathrm{~b}$ & $23.0 \mathrm{a}$ & $26.7 \mathrm{~b}$ \\
\hline Se $\left(\mathrm{mg} \mathrm{kg}^{-1}\right)$ & $12.4 \mathrm{a}$ & $53.4 \mathrm{~b}$ & $27.8 \mathrm{a}$ & $40.5 \mathrm{~b}$ & $21.1 \mathrm{a}$ & $38.9 \mathrm{~b}$ & $18.9 \mathrm{a}$ & $23.5 \mathrm{~b}$ \\
\hline
\end{tabular}

Means marked in rows with different letters $(a-b)$ for the individual cereal species are significantly different $(p=0.05)$; $C S=$ conventional system; OS = organic system

The organic farming system contributed to a significantly higher Se content in cereal grain relative to conventional farming (Table 6). Organic farming resulted in a 4 times increase in the Se content in spring wheat grain and a 1.4 times increase in the Se content in winter wheat grain. As influenced by organic farming, the Se content in spelt grain increased by about $46 \%$ and in millet grain by about $20 \%$. 


\section{Cereal grain yield}

The farming system had different effects on the grain yield of the cereals in question (Table 7). Organic farming resulted in decreased yield in both spring and winter wheat by $12 \%$ and $11 \%$, respectively. Spelt wheat and proso millet, in turn, produced yields at a similar (statistically insignificant) level under conventional and organic farming conditions.

\begin{tabular}{|c|c|c|}
\hline \multirow{2}{*}{ Species } & \multicolumn{2}{|c|}{ Farming system } \\
\hline & Conventional & Organic \\
\hline Spring wheat & 4.21 a A & $3.72 \mathrm{~b} \mathrm{~A}$ \\
\hline Winter wheat & 5.11 a B & $4.53 \mathrm{~b} \mathrm{~B}$ \\
\hline Spelt wheat & 2.97 a C & 2.69 a C \\
\hline Proso millet & 1.64 a D & 1.42 a D \\
\hline
\end{tabular}

\section{Discussion}

The chemical composition of agricultural produce depends on many factors, which include agronomic factors, such as fertilization, tillage, previous crop and crop protection, soil, genetic (varietal characters) and climatic factors as well as plant growth stage. These factors may have varied effects depending on the crop plant species, the component evaluated, or the region in which the research was conducted (Lasztity 1999, Demirbas 2005, Škrbić and Onija 2007, Jablonskyte-Rasce et al. 2013, Kraska et al. 2013). For this reason, the results obtained in the present experiment sometimes diverge from those obtained by other researchers.

The studies of some authors show that different methods of soil activation used in organic farming (cover cropping, Effective Microorganisms, the soil conditioners UGmax and Eko-Użyźniacz) have an effect on increasing the organic carbon and humus content in the soil (Bruce et al. 1990, Jaskulski and Jaskulska 2004). Likewise, in the present study in which we used the fertilizer Humac Agro containing humic acids, an increase in the content of some soil characteristics ( $\mathrm{Mg}$, humus) was obtained. In the opinion of Katkat et al. (2009), humic acids increase seed germination power, seedling growth, root mass formation, stem development, and the uptake of macroand micronutrients from the soil. This fact could have had an indirect positive effect on the more favorable nutritional composition of grain of the studied cereals compared to the treatments with NPK mineral fertilization (the conventional system).

Dietary fiber primarily affects intestinal peristalsis and the rate of passage of food through the alimentary tract depends on its amount (Śmiechowska and Jurasz 2014). Cereals provide about $50 \%$ of the daily dietary fiber requirement (Anderson and Bridges 1988). An analysis conducted by Górecka et al. (2011) showed that over the last decade the daily dietary fiber intake in Poland had significantly decreased, but it is still in accordance with the nutritional recommendations. In our study, all the cereals evaluated were characterized by a high dietary fiber content. Significantly the highest content was found in proso millet, while the lowest one in winter wheat. Unlike the present experiment, Biel and Maciorowski (2012) obtained a higher dietary fiber content in winter wheat grain relative to spring wheat. Organic farming significantly increased the grain dietary fiber content only in spelt wheat.

The amino acid composition determines the nutritional value of protein. The following amino acids are the most important in nutrition: Lys, sulfur amino acids, Thr, Trp, Val, and Ile (Biel and Maciorowski 2012). According to the research of Kalinova and Moudry (2006), despite that the protein content in proso millet is at a level similar to that of wheat (about $11.6 \%$ of dry weight), proso millet protein is much richer in amino acids such as Leu, lle, and Met. Due to this, the quality of protein of this species was higher, which was confirmed by the EAAI higher by $51 \%$. In the present study, the EAAI of proso millet was similar to that calculated for spring wheat. In analyzing the amino acid composition of some spelt wheat cultivars, Waga et al. (2002) showed them to have a higher content of all amino acids compared to common wheat, in particular Glu, Pro, Ser, Tyr, and essential amino acids. In the study by Grela (1997), the amino acid composition of Triticum spelta grain was similar to that of common wheat and triticale.

When comparing the protein amino acid composition found in the present study to the amino acid content in common wheat, spelt and proso millet grain determined by Matuz et al. (2000), significant differences can be noticed. In the study by Matuz et al. (2000), common wheat contained more Asn, Glu, Tyr, Val, Phe, Ile, and Leu, but less Met, whereas the content of the other amino acids in grains was at a similar level to that found in the present study. 
In spelt wheat, similar differences in the amino acid composition were observed between the results presented in this paper and those obtained by Matuz et al. (2000), but the above-mentioned authors additionally found a larger amount of Arg. In the case of proso millet, Matuz et al. (2000) found more Asn, Tyr, Phe and Ile in its grain, but less Thr, Met, Leu and Pro.

Detailed evaluation of the mineral composition of agricultural produce is very important because, as shown by Fan et al. (2008), the content of $\mathrm{Zn}, \mathrm{Fe}, \mathrm{Cu}$ and $\mathrm{Mn}$ in cereal crops in the USA had decreased since 1960, which coincided with the introduction of semi-dwarf high-yield wheats into cultivation. In Finland Ekholm et al. (2007) evaluated the availability of macro- and micronutrients in cereal food products, fruit and vegetables and compared their results with those obtained 30 years earlier. They demonstrated significant changes in the availability of elements in evaluated products, since in most cases their lower amounts were found and only the amount of Se had increased substantially as a result of adding this element to mineral fertilizers.

In the present experiment, compared to the results obtained by Suchowilska et al. (2012), spring wheat grains were characterized by almost a half lower content of $\mathrm{K}$ and $\mathrm{Mg}$, an over $20 \%$ lower content of $\mathrm{Ca}$ and $\mathrm{Zn}$ as well as a similar content of $\mathrm{Cu}, \mathrm{Mn}$ and $\mathrm{Fe}$. On the other hand, spelt wheat contained more than half less $\mathrm{K}$ and $\mathrm{Mg}$, more than $20 \%$ less $\mathrm{Ca}, \mathrm{Cu}, \mathrm{Fe}$ and $\mathrm{Zn}$ as well as a comparable amount of $\mathrm{Mn}$. In the research by Lacko-Bartošová (2010), spelt grain was found to have significantly larger amounts of $\mathrm{K}, \mathrm{Ca}$ and $\mathrm{Mg}$, which was not confirmed by our analysis. Compared to the results obtained by Kraska et al. (2013), we found a similar content of $\mathrm{N}$ and $\mathrm{Mn}$ in spelt grains as well as a lower content of $\mathrm{K}, \mathrm{Mg}$, Zn and $\mathrm{Cu}$. Zhao et al. (2009) showed that the Fe content in grain of common bread wheats ranged between 28.8 and $50.8 \mathrm{mg} \mathrm{kg}^{-1}$ (on average $38.2 \mathrm{mg} \mathrm{kg}^{-1}$ ), while the amount of this element in spelt grains was more stable and ranged $37.9-44.1 \mathrm{mg} \mathrm{kg}^{-1}$ (on average $41,8 \mathrm{mg} \mathrm{kg}^{-1}$ ). The amount of $\mathrm{Zn}$ in grain of both wheats was similar; in common wheat it was on average $21.4 \mathrm{mg} \mathrm{kg}^{-1}$, while in spelt wheat $22.9 \mathrm{mg} \mathrm{kg}^{-1}$. The availability of Se in common wheat grain varied markedly, ranging from 32.9 to $237.9 \mu \mathrm{g} \mathrm{kg}{ }^{-1}$, whereas in spelt wheat much lower differences were found in the amount of Se in grain; the minimum amount was $125.1 \mathrm{\mu g} \mathrm{kg}^{-1}$, while the maximum amount $244.0 \mu \mathrm{g} \mathrm{kg}^{-1}$.

In this study, the agricultural production system significantly modified the content of most macro- and micronutrients in grain. Organic farming caused an increase in the availability of $\mathrm{Cu}$ and Se in grains of all the four cereals evaluated. Spring wheat was found to have significantly less of all the other minerals. In winter wheat, the farming system did not modify the amount of $\mathrm{N}$ and $\mathrm{Mg}$, but significantly reduced the content of $\mathrm{K}, \mathrm{Ca}, \mathrm{Mn}, \mathrm{Fe}$ and $\mathrm{Zn}$. In spelt wheat, apart from $\mathrm{Cu}$ and $\mathrm{Se}, \mathrm{Mg}, \mathrm{Mn}$ and Fe were found to increase under organic farming conditions, while all the other macro- and micronutrients occurred in smaller amounts. In the case of proso millet, the production system did not differentiate the availability of $\mathrm{N}, \mathrm{K}$ and $\mathrm{Mg}$ in grains, but organic farming resulted in a decrease in the Ca content and an increase in the content of Mn, Fe and $\mathrm{Zn}$ (apart from Cu and Se). The results obtained by other authors vary significantly. Worthington (2001) showed that the differences in the content of nutrients in organically and conventionally grown plants is dependent on the plant species. Generally, a higher content of $\mathrm{Fe}, \mathrm{P}$ and $\mathrm{Mg}$ was found in organic crops. Nevertheless, there were also some exceptions. In organic carrot, compared to conventionally grown carrot, less vitamin C was found, while in spinach less $\mathrm{Mg}$. In the study by Warman and Havard (1997), the differences in the availability of macro- and micronutrients in carrot roots varied between years. Under organic farming, this study found a higher content of $\mathrm{Na}, \mathrm{Mg}, \mathrm{S}$ and $\mathrm{B}$ as well as a lower content of $\mathrm{N}, \mathrm{Mn}, \mathrm{Cu}$ and $\mathrm{Zn}$ each year in which the crops were fertilized with compost. In organically grown cabbage, there was less $\mathrm{N}$ and $\mathrm{Mn}$, but more $\mathrm{Cu}$ and $\mathrm{Zn}$. In another experiment conducted by Warman and Havard (1998), organic potato tubers, compared to conventionally grown potato, were shown to have more $\mathrm{P}, \mathrm{K}, \mathrm{Na}$ and $\mathrm{Mg}$, but less $\mathrm{Mn}$. Maize cobs were not found to show clear relationships concerning the effect of farming system on the content of the elements investigated. In the study of Wiśniowska-Kielian and Klima (2007), the average contents of $\mathrm{Fe}, \mathrm{Zn} \mathrm{Mn}$, and $\mathrm{Cu}$ in winter wheat grain showed small differences, but they were however slightly higher than in grain from conventional farms. On the other hand, Mazurkiewicz (2005) revealed that grain from organically grown common wheat contained much less $\mathrm{Fe}, \mathrm{Zn}$ and $\mathrm{Cd}$, but more $\mathrm{Mg}$ and $\mathrm{Pb}$ than grain from conventional crops. According to Ciołek et al. (2012), common wheat grains from organic farming contained more $\mathrm{Mn}, \mathrm{Fe}, \mathrm{Zn}$, $\mathrm{Ca}$ and $\mathrm{Mg}$ compared to those from conventional farms. Nevertheless, farming system was not found to show a clear effect on $\mathrm{Ca}$ and $\mathrm{Mg}$ content.

Phenolic compounds are a numerous and important group of substances with strong antioxidant properties. The study of Pasqualone et al. (2014) showed a positive correlation between the grain content of soluble phenolics and antioxidant activity. A substantial amount of these compounds is also found in cereal grain, in particular in whole grains and bran (Baublis et al. 2000, Zieliński et al. 2012, Shahidi and Chandrasekara 2013). 
Research has revealed that cereal species are characterized by varied availability of individual phenolic acids (Shahidi and Chandrasekara 2013, Rybka et al. 1993, Lempereur et al. 1997). In the present study, spelt grains were richest in phenolics, much lower amounts of these compounds were found in wheat, while proso millet was poorest in this respect. Under the organic farming system, the study revealed a significantly higher o-dihydroxyphenol content in grains of all the cereals in question. Similar results were also obtained by Żuchowski et al. $(2009,2011)$ who found that the total phenolic acid content in common wheat was higher in organic grain than in conventionally grown grain. They also demonstrated significant differences in the proportions of individual phenolic acids both between farming systems and wheat cultivars.

Both numerous field experiments and agricultural practice prove that yields of crops grown under the organic system are lower compared to conventional production (Cassman 1999, Seufert et al. 2012). In this study, under organic farming conditions the yield was lower from $9.4 \%$ in the case of spelt wheat to $13.4 \%$ for proso millet. Seufert et al. (2012) report that under the organic system, compared to conventional cropping carried out under the same soil and climatic conditions, a reduction in yield can reach even $34 \%$. Spelt wheat, as an old, extensive and resistant cereal, is recommended for growing under the organic system (Tyburski and Żuk-Gołaszewska 2005) and that is why in the present experiment this crop responded best to organic cropping. Proso millet, on the other hand, is very easily infested by weeds and very frequently this is the element that determines yields of this crop grown under organic farming.

\section{Conclusions}

The results obtained in our study show that spelt wheat is a cereal well-suited to organic farming, followed by proso millet. The above-mentioned cereals are tolerant to the abandonment of use of agricultural chemicals and at the same time are characterized by a more favorable grain chemical composition under organic farming conditions.

This study has confirmed that spring and winter wheat are cereals whose productivity increases when the recommended rates of mineral fertilization (NPK) and chemical protection against weeds and fungal diseases are used. However, taking into consideration the quality of wheat grain in terms of its content of health-enhancing components (o-dihydroxyphenols, selenium, some amino acids such as Val, Met and Trp), organic farming proves to be more beneficial.

\section{Acknowledgments}

Research was supported by the Ministry of Science and Higher Education of Poland as a part of the statutory activities of the Department of Herbology and Plant Cultivation Techniques, University of Life Sciences in Lublin.

\section{References}

Acko, D.K. 2012. Importance and possibilities of proso millet (Panicum miliaceum L.) production for human nutrition, and animal feed in Slovenia. Journal of Food, Agriculture \& Environment 10: 636-640.

Anderson, J.W. \& Bridges, S.R. 1988. Dietary fiber content of selected foods. American Journal of Cardiology 60: 17-22.

Baltensperger, D.D., Frickel, G.E., Nelson, L.A., Krall, J.M., Vigil, M., Hain, J., Johnson, J., Stymiest, C. \& Rickertsen J.R. 2004. Registration of 'Horizon' proso millet. Crop Science 44: 688-689.

Baltensperger, D.D., Nelson, L.A. \& Frickel, G.E. 1997. Registration of 'Sunrise' proso millet. Crop Science 37: 1380.

Baublis, A.J., Lu, C., Clydesdale, F.M. \& Decker, E.A. 2000. Potential of wheat-based cereals as a source of dietary antioxidants. Journal of the American College of Nutrition 19: 308S-311S.

Bavec, M., Narodoslawsky, M., Bavec, F. \& Turinek, M. 2011. Ecological impact of wheat and spelt production under industrial and alternative farming systems. Renewable Agriculture \& Food Systems 27: 242-250.

Biel, W. \& Maciorowski, R. 2012. Assessing nutritional value of grains of selected wheat cultivars. ŻYWNOŚĆ. Nauka. Technologia. Jakość 2: 45-55.

Brocic, Z., Milosevic, D., Macak, M. \& Tyr, S. 2008. Influence of an organic and conventional systems on chemical composition of potato tubers. Cereal Research Communications 36: 679-682.

Bruce, R.R., Langdale, G.W. \& West, L.T. 1990. Modification of soil characteristics of degraded soil surfaces by biomass input and tillage affecting soil water regime. In Transactions 14th International Congress of Soil Science. Kyoto, Japan, VI: 4-9.

Cassman, K.G. 1999. Ecological intensification of cereal production systems: Yield potential, soil quality, and precision agriculture. Proceedings of the National Academy of Sciences of the United States of America 96: 5952-5959.

Ciołek, A., Makarska, E., Wesołowski, M. \& Cierpiała, R. 2012. Content of selected nutrients in wheat, barley and oat grain from organic and conventional farming. Journal of Elementology 2: 181-189. 
Demirbas, A. 2005. $\beta$-Glucan and mineral nutrient contents of cereals grown in Turkey. Food Chemistry 90: 773-777.

Duthie, G.G., Duthie, S.J. \& Kyle, J.A.M. 2000. Plant polyphenols in cancer and heart disease: implications as nutritional antioxidants. Nutrition Research Reviews 13: 79-106.

Ekholm, P., Reinivuo, H., Mattila, P., Pakkala, H., Koponen, J., Happonen, A., Hellström, J. \& Ovaskainen, M.L. 2007. Changes in the mineral and trace element contents of cereals, fruits and vegetables in Finland. Journal of Food Composition \& Analysis 20: 487-495.

Fan, M.S., Zhao, F.J., Fairweather-Tait, S.J., Poulton, P.R., Dunham, S.J. \& McGrath, S.P. 2008. Evidence of decreasing mineral density in wheat grain over the last 160 years. Journal of Trace Elements in Medicine \& Biology 22: 315-324.

Górecka, D., Janus, P., Borysiak-Marzec, P. \& Dziedzic, K. 2011. Analysis of consumption of dietary fiber and its fractions in Poland in the last decade based on the statistical yearbook data. Problemy Higieny i Epidemiologii 92: 705-708.

Grela, E.R. 1996. Nutrient composition and content of antinutritions factors in spelt (Triticum spelta L.) cultivars. Journal of The Science of Food \& Agriculture 71: 399-404.

Hajšlová, J., Schulzová, V., Slanina, P., Janné, K., Hellenäs, K.E. \& Andersson, Ch. 2005. Quality of organically and conventionally grown potatoes: Four-year study of micronutrients, metals, secondary metabolites, enzymic browning and organoleptic properties. Food Additives \& Contaminants 22: 514-534.

Houba V.J.G., Novozamsky I., \& Temminghoff E. 1994. Soil Analysis Procedures: Extraction with $0.01 \mathrm{M} \mathrm{CaCl}_{2}$. Soil and Plant Analysis, Part 5. Wageningen, The Netherlands. 66 p.

Jablonskyte-Rasce, D., Maiksteniene, S. \& Mankeviciene, A. 2013. Evaluation of productivity and quality of common wheat (Triticum aestivum L.) and spelt (Triticum spelta L.) in relation to nutrition conditions. Zemdirbyste-Agriculture 100: 45-56.

Jaskulski, D. \& Jaskulska, I. 2004. Effect of fertilisation with straw, stubble intercrops, and varied tillage on some properties of soil in the crop-rotation link: winter wheat - spring barley. Acta Scientiarum Polonorum, Agricultura 3: 151-163.

Kalinova, J. \& Moudry, J. 2006. Content and Quality of Protein in Proso Millet (Panicum miliaceum L.) Varieties. Plant Foods for Human Nutrition 61: 43-47.

Katkat, A.V., Celik, H., Turan, M.A. \& Asik, B.B. 2009. Effects of soil and foliar applications of humic substances on dry wright and mineral nutrients uptake of wheat dunder calcareous soil conditions. Australian Journal of Basis \& Applied Sciences 3: 1266-1273.

Kraska, P., Andruszczak, S., Kwiecińska-Poppe, E. \& Pałys, E. 2013. Effect of chemical crop protection on the content of some elements in grain of spelt wheat (Triticum aestivum ssp. spelta). Journal of Elementology 1: 79-90.

Lacko-Bartošová, M. 2010. Nutritional quality and antioxidant capacity of Triticum spelta varieties. Journal of Ecology \& Health 14: 290-294.

Lasztity, B. 1999. Microelement uptake of millet (Panicum miliaceum L.) in the course of the vegetation period. Novenytermeles 48: $103-110$

Lempereur, I., Rouaur, X. \& Abecassis, J. 1997. Arabinoxylan and ferulic acid variation in durum wheat (Triticum durum) and distribution in milling fractions. Journal of Cereal Science 25: 103-107.

Mäder, P., Hahn, D., Dubois, D., Gunst, L., Alföldi, T., Bergmann, H., Oehme, M., Amadó, R., Schneider, H., Graf, U., Velimirov, A., Fließbach, A. \& Niggli, U. 2007. Wheat quality in organic and conventional farming: results of 21 year field experiment. Journal of The Science of Food \& Agriculture 87: 1826-1835.

Matuz, J., Bartók, T., Mórocz-Salamon, K. \& Bóna, L. 2000. Structure and potential allergenic character of cereal proteins: I. Protein content and amino acid composition. Cereal Research Communications 28: 263-270.

Mazurkiewicz, J. 2005. Comparison of the technological quality of wheat and rye cultivated in conventional and ecological farm conditions. Acta Agrophysica 6: 729-741.

Pasqualone, A., Delvecchio, L. N., Mangini, G., Taranto, F., \& Blanco, A. 2014. Variability of total soluble phenolic compounds and antioxidant activity in a collection of tetraploid wheat. Agricultural and Food Science 23: 307-316.

Piironen, V., Toivo, J. \& Lampi, A.M. 2002. Plant sterols in cereals and cereal products. Cereal Chemistry 79:148-154.

Ruibal-Mendieta, N.L., Dekeyser, A., Delacroix, D.L., Mignolet, E., Larondelle, Y. \& Meures, M. 2004. The oleate/palmitate ratio allows the distinction between whole mealm of spelt (Triticum spelta L.) and winter wheat (T. aestivum L.). Journal of Cereal Science 39: 413-415.

Rybka, K., Sitarska, J. \& Raczyńska-Bojanowska, K. 1993. Ferulic acid in rye and wheat grain and grain dietary fiber. Cereal Chemistry 70: 55-59.

Seufert, V., Ramankutty, N. \& Jonathan, F.A. 2012. Comparing the yields of organic and conventional agriculture. Nature 485: 229-234.

Shahidi, F. \& Chandrasekara, A. 2013. Millet grain phenolics and their role in disease risk reduction and health promotion: A review. Journal of Functional Foods 5: 570-581.

Škrbić, B. \& Onija, A. 2007. Multivariate analyses of microelement contents in wheat cultivated in Serbia (2002). Food Control 18: $338-345$.

Śmiechowska, M. \& Jurasz, M. 2014. Content of crude fiber in selected cereal products. Problemy Higieny i Epidemiologii 95: 429-432.

Suchowilska, E., Wiwart, M., Kandler, W. \& Krska, R. 2012. A comparison of macro- and microelement concentrations in the whole grain of four Triticum species. Plant, Soil \& Environment 58: 141-147.

Tyburski, J. \& Żuk-Gołaszewska, K. 2005. Spelt wheat: the cereal of our ancestors. Postępy Nauk Rolniczych 4: 3-13.

Waga, J., Węgrzyn, S., Boros, D. \& Cygankiewicz, A. 2002. Wykorzystanie orkiszu (Triticum aestivum ssp. spelta) do poprawy właściwości odżywczych pszenicy zwyczajnej (Triticum aestivum ssp. vulgare). Biuletyn IHAR 221: 3-14.

Wang, Z.H., Li, S.X. \& Malhi, S. 2008. Effects of fertilization and other agronomic measures on nutritional quality of crops. Journal of The Science of Food \& Agriculture 88: 7-23. 
Warman, P.R. \& Havard, K.A. 1997. Yield, vitamin and mineral contents of organically and conventionally grown carrots and cabbage. Agriculture, Ecosystems \& Environment 61: 155-162.

Warman, P.R. \& Havard, K.A. 1998. Yield, vitamin and mineral contents of organically and conventionally grown potatoes and sweet corn. Agriculture, Ecosystems \& Environment 68: 207-216.

Wiśniowska-Kielian, B. \& Klima, K. 2007. Comparison of microelement contents in the winter wheat grain from organic and conventional farms. Journal of Research \& Applications in Agricultural Engineering 52:100-103.

Worthington, V. 2001. Nutritional Quality of Organic Versus Conventional Fruits, Vegetables, and Grains. The Journal of Alternative \& Complementary Medicine 7: 161-173.

Zhao, F.J., Su, Y.H., Dunham, S.J., Rakszegi, M., Bedo, Z., McGrath, S.P. \& Shewry, P.R. 2009. Variation in mineral micronutrient concentrations in grain of wheat lines of diverse origin. Journal of Cereal Science 49: 290-295.

Zieliński, H., Achremowicz, B. \& Przygodzka, M. 2012. Antioxidants in cereal grains. Żywność. Nauka. Technologia. Jakość 80: 5-26.

Żuchowski, J., Jończyk, K., Pecio, L. \& Oleszek, W. 2011. Phenolic acid concentrations in organically and conventionally cultivated spring and winter wheat. Journal of The Science of Food \& Agriculture 91: 1089-1095.

Żuchowski, J., Kapusta, I., Szajwaj, B., Jończyk, K. \& Oleszek, W. 2009. Phenolic acid content of organic and conventionally grown winter wheat. Cereal Research Communications 37: 189-197. 